\title{
Asia (2018)
}

\author{
Emika Tokunaga*
}

There is no binding multilateral treaty for all Asian countries with a view to addressing disaster management. However, on the sub-regional plan, two legally binding regional treaties have been adopted in Southeast Asia and South Asia: respectively, the ASEAN Agreement on Disaster Management and Emergency Response (AADMER) ${ }^{1}$ and the SAARC Agreement on Rapid Response to Natural Disasters (SARRND). ${ }^{2}$

The AADMER, adopted in July 2005 and entered into force in December 2009, is the regional treaty on legal preparedness for emergency response and disaster risk management among the ten member States of the Association of Southeast Asia (ASEAN) aimed at enhancing each national framework and regional cooperation. The objective of the AADMER is to provide effective mechanisms to achieve substantial reduction of disaster losses in lives and in the social, economic and environmental assets of the State parties, as well as to jointly respond to disaster emergencies through concerted national efforts and intensified regional and international co-operation, also taking into account sustainable development. ${ }^{3}$

The AADMER lays the responsibility on two organs of the ASEAN relating to disaster management: Disaster Management and Humanitarian Assistance Division (DMHA) and the ASEAN Coordinating Centre for Humanitarian Assistance on Disaster Management (AHA Centre). The DMHA serves as the AADMER secretariat to facilitate and monitor progress in the implementation of the AADMER as well as arrange for and service meetings of the Conference of the Parties. The AHA Centre was established in November 2011 based on a legal binding agreement ${ }^{4}$ implementing art. 20 of the AADMER. This Centre serves as primary ASEAN regional coordinating agency through facilitating cooperation and the coordination of emergency response and disaster management

* Visiting Researcher, Osaka School of International Public Policy, Osaka University.

1 ASEAn Agreement on Disaster Management and Emergency Response (AADMER), 26 July 2005, 157 .

2 SAARC Agreement on Rapid Response to Natural Disasters (SARRND), 11 November 2011.

3 AADMER (n. 1) art. 2.

4 Agreement on the Establishment of the ASEAn Coordinating Centre for Humanitarian Assistance on Disaster Management, 17 November 2011. 
among the parties and with relevant $\mathrm{UN}$ and international organisations. ${ }^{5}$ The ASEAN is also further reinforcing existing bodies in order to support the implementation of the AADMER. Based on the endorsement at the 14th ASEAN Summit in 2009, the Secretary General of the ASEAN (SGA) shall serve as the ASEAN coordinator on humanitarian assistance, which can be activated any time in the event of a major disaster, whether it be a natural disaster or a pandemic, at the request of the affected member State or with the consent of it, or if there is no objection by the affected member State upon the offer of assistance made by the SGA. ${ }^{6}$ The ASEAN Committee on Disaster Management (ACDM), the functions of which were strengthened in $2003,{ }^{7}$ consists of representatives of national disaster management organisations (NDMOs) from each ASEAN member State, overseeing the development, implementation, and monitoring of the implementation of the AADMER and the AAdMER Work Programme. ${ }^{8}$ Under the AADMER, the ASEAN also developed further mechanisms and tools on disaster management, including the Standard Operating Procedure for Regional Standby Arrangement and Coordination of Joint Disaster Relief and Emergency Response Operation (SASOP), ${ }^{9}$ ASEAN Regional Disaster Emergency Response Simulation (ARDEX), ${ }^{10}$ and ASEAN-Emergency Response and Assessment Team (ERAT). ${ }^{11}$ In February 2016 the ADCM endorsed the AADMER Work Programme 2016-2020, ${ }^{12}$ which succeeded Programme 2010-2015 and was launched in April 2016, thereby positioning the ASEAN as a possible global model on disaster management and also emphasising the ASEAN identity. ${ }^{13}$ In September 2016, a new declaration was signed to achieve faster response, mobilise greater resources, and establish strong coordination for enhancement of further collective response to disasters. ${ }^{14}$

Aadmer (n. 1) art. 20, Annex; Agreement on the Establishment of the ASEAN Coordinating Centre (n. 4) art. 3.

asean, 'AAdmer Work Programme 2016-2020', (2016) Annex 6, available at <https:// www.asean.org/wp-content/uploads/2016/o2/AADMER-Work-Programme2016-2020-v1.6.pdf> last accessed (as any subsequent URL) on 29 June 2019. Regional Office for Asia and the Pacific of the UN Office for the Coordination of Humanitarian (ROAP-OCHA), 'Disaster Response in Asia and The Pacific: A Guide to International Tools and Services' (2017), available at <https://www.unocha.org/sites/unocha/files/ ROAP_DisasterGuide.pdf $>, 48$.

8 Ibid.; AADMER Work Programme (n. 6) Annex 2.

9 ROAP-OCHA (n. 7) 11-12.

$10 \quad$ Ibid., 97.

11 Ibid., 69-71.

12 AADMER Work Programme (n. 6) 9.

13 Ibid., 8-9.

14 ASEAN, 'ASEAn Declaration on One asean, One Response: ASEAn Responding to Disasters as One in the Region and Outside the Region' (16 September 2016), available at 
Moving to the South Asia region, the SARRND is a regional treaty on natural disaster management between the SAARC member states, based on the declaration adopted at the 15th SAARC Summit in August 2008, in order to create and develop a rapid response mechanism in the event of natural disasters through a coordinated and planned approach. ${ }^{15}$ Signed by the member States in November 2011 and entered into force in September 2016, this agreement aims at reinforcing existing national disaster response mechanisms and institutions to develop an efficient disaster management system and a strengthened emergency response system, a system which includes the SAARC Disaster Management Centre (initiated in 2006). ${ }^{16}$ The objectives of the SAARND are to provide effective regional mechanisms for rapid response to natural disasters so that the state parties could achieve a substantial reduction in losses of lives and social, economic and environmental assets due to disaster, and to jointly respond to disaster emergencies through concerted national efforts and intensified regional cooperation. ${ }^{17}$ The 2oth SAARC Summit will be held in 2019 where the implementation of the SARRND at regional and national level might be discussed.

As previously mentioned, in East Asia there is no legally binding treaty to response to disaster situations at a regional level. However, among Japan, Republic of Korea (вок), and the People's Republic of China (China), periodical summits have been organised since 2003 in order to promote and strengthen a tripartite cooperation also with regards to disaster management. ${ }^{18}$ In December 2008 , these three countries announced a new plan to further enhance their cooperation in three areas:

i. developing comprehensive disaster management framework,

ii. developing measures and systems to reduce vulnerability to disasters and to minimise damage from disasters, and

$<$ https://asean.org/storage/2016/og/Declaration-on-One-ASEAN-One-Response.pdf >; ROAP-OCHA (n. 7) 12, 27.

15 SAARC, 'Fifteenth SAARC Summit Colombo, Declaration: Partnership for Growth for Our People' (2-3 August 2008), available at <http://saarc-sec.org/uploads/digital_library_doc: ument/15_-_Colombo,_15th_Summit_2-3_August_2008_-_for_printing.pdf >, para. 14.

16 Stacey White, A Critical Disconnect: The Role of SAARC in Building the DRM Capacities of South Asian Countries (Brookings Institution 2015) 7.

17 SARRND (n. 2) art. II.

18 Ministry of Foreign Affairs of Japan, 'Joint Declaration on the Promotion of Tripartite Cooperation among, Japan, the People's Republic of China and the Republic of Korea' (7 October 2003), available at <https://www.mofa.go.jp/region/asia-paci/asean/conference/ asean3/jointo310.html>, para. III, 4. 
iii. strengthening effective disaster management at the national, local and community levels. ${ }^{19}$

In 2009, as a trilateral body, they decided to have a rotating Head of Disaster management, thereby beginning the implementation of their cooperation. ${ }^{20}$ In December 2010, those three countries concluded a legally binding agreement to establish a secretariat in order to efficiently promote and manage their own trilateral cooperation, as decided at the Third Trilateral Summit held in May 2010. ${ }^{21}$ The secretariat was thereby launched in Seoul in September 2011. At the fourth Trilateral Summit, held in May 2011 against the backdrop of the Great East Earthquake which occurred in Japan the previous March, those three countries decided to further enhance their cooperative framework. This included: conducting exercises, enhancing capacity, ensuring quick and smooth communication in disaster situations, enhancing coordination in providing and receiving assistance, promoting technology and enhancing information-sharing on disaster management. ${ }^{22}$

\subsection{Progress in 2018}

From 26 to 28 June 2018 the 32 nd Meeting of the ACDM was held in Kuala Lumpur in conjunction with the 8th Governing Board Meeting of the AHA Centre, the 9th Joint Task Force Meeting to Promote Synergy with Other Relevant ASEAN Bodies on Humanitarian Assistance and Disaster Relief, and the 5th AADMER Partnership Conference. In these meetings, the ACDM agreed to pursue new initiatives on women, peace and security, as well as strengthen efforts on gender mainstreaming in disaster risk reduction (DRR) and climate change adaptation in order to further enhance the role of women as key humanitarian actors throughout disaster management processes. ${ }^{23}$

On 4 October 2018, the 7 th Meeting of the Conference of the Parties to the AADMER, in conjunction with the 6th ASEAN Ministerial Meeting on Disaster

19 Ministry of Foreign Affairs of Japan, 'Japan-China-ROK Trilateral Summit, Trilateral Joint Announcement on Disaster Management Cooperation' (13 December 2008), available at <https://www.mofa.go.jp/region/asia-paci/jck/summito812/disaster.html>.

20 Ibid.

21 Agreement on the Establishment of the Trilateral Cooperation Secretariat among the governments of Japan, The People's Republic of China and The Republic of Korea, 16 December 2010.

22 Ministry of Foreign Affairs of Japan, 'Cooperation on Disaster Management' (22 May 2011), available at $<$ https://www.mofa.go.jp/region/asia-paci/jck/summit1105/disaster_managet ment.html>.

23 ASEAN, 'ASEAN to mainstream gender perspective in disaster management strategies' (29 June 2018), available at <https://asean.org/asean-mainstream-gender-perspectivedisaster-management-strategies/?highlight=AADMER\%202018>. 
Management (AMmdM) was convened in Putrajaya, Malaysia. The Ministers encouraged to promptly finalise the Memorandum of Understanding (MOU) between the ASEAN and the Russian Federation on Cooperation in the Field of Disaster Management, and the MOU with the International Federation on the Red Cross and Red Crescent Societies (IFRC) to strengthen community resilience in Southeast Asia. ${ }^{24}$ They also urged to conclude the project arrangement for a work plan between the ASEAN and China in order to facilitate the provision of information, communications technology equipment, and capacity building activities in the near future. ${ }^{25}$ With regard to financial issues, the ministers also decided to increase the annual and equal contribution of ASEAN member states to the A HA Centre Fund, for a period of 5 years, from USD 50.000 to USD 90.00o, starting from $2019 .{ }^{26}$ In addition, from 4 to 10 November 2018, the ARDEX to simulate regional disaster emergency response took place in $\mathrm{Ci}$ legon, Indonesia, a place subject to earthquake and tsunami as well as being exposed to industrial hazards. ${ }^{27}$ Since 2013, the ARDEX has been co-organised biennially by the ACDM and the AHA Centre with the host country in order to test and validate ASEAN SASOP and ASEAN's preparedness and readiness in the event of disasters. ${ }^{28}$ More than 100 international delegations from ASEAN member States and outside the ASEAN participated in the ARDEX in order to test their response to scenarios including multiple risks in industrial sites during the occurrence of an earthquake, a tsunami, and a leakage of hazardous materials. $^{29}$

Regarding financial resilience, on December 14 2018, a MOU for the establishment of the Southeast Asia Disaster Risk Insurance Facility (SEADRIF) was signed by the six representatives of the finance ministries (Cambodia, Indonesia, Japan, Lao PDR, Myanmar, and Singapore) at the margins of the ASEAN +3

24 ASEAN, 'Chairman's Statement of the 7th Meeting of the Conference of the Parties to the ASEAn Agreement on Disaster Management and Emergency Response and the 6th ASEAN Ministerial Meeting on Disaster Management (4 October 2018)', available at <https:// asean.org/storage/2018/10/Chairman-Statement-for-6th-AMMDM-7th-COP-to-AADMER-CLEAN.pdf $>$, para. 11 .

25 Ibid.

26 Ibid., para. 17.

27 AHA Centre, 'Press Release: Indonesia Hosts the 7th ASEAN Regional Disaster Emergency ResponseSimulation Exercise' (5 November 2018), availableat $<$ https://ahacentre.org/press -release/press-release-the-aha-centre-launches-the-first-asean-risk-monitor-and-disas ter-management-review-indonesia-hosts-the-7th-asean-regional-disaster-emergency -response-simulation-exercise/>.

28 ROAP-OCHA (n. 7) 97.

29 AHA Centre (n. 27). 
Finance and Central Bank Deputies Meeting in Busan, Rок. ${ }^{30}$ The SEADRIF, in partnership with the Work Bank, will be the first regional facility in Asia (for the benefit of all ASEAN countries initially) comprising a trust and an insurance company in Singapore. ${ }^{31}$ This facility will provide ASEAN countries with financial solutions and technical advice (such as a regional catastrophe risk insurance pool) in order to increase their financial resilience to climate and disaster risks. ${ }^{32}$

Furthermore, in 2018 the AHA Centre engaged in one preparedness mission (in Rakhine State of Myanmar in January) and six response missions: Yangon Landfill Fire in Myanmar in April; the mission to Lao PDR and Myanmar affected by Tropical Storm 11, which is also known as Son Tinh or Henry from July to August; the mission to Lambok Earthquakes in Indonesia in July; the mission to the Philippines affected by Typhoon Mangkhut in September; and the mission to Indonesia affected by Central Sulawesi Earthquake and Tsunami in September. ${ }^{33}$ The AHA Centre provided direct assistance and coordinated relief materials, including information management and communications, for each of those missions in collaboration with each affected government and its NDMOs, as well as the ERAT, among others. ${ }^{34}$

\section{Disaster Risk Reduction in Asia}

In the area of DRR we can consider the activities of one permanent institution, the Asian Disaster Reduction Centre (ADRC), and a biennial ministerial conference, the Asian Ministerial Conference on Disaster Risk Reduction (AMCDRR). They both aim to enhance regional DRR cooperation in Asia, as well as promoting the implementation of the Sendai Framework for Disaster Risk Reduction 2015-2030 (Sendai Framework) ${ }^{35}$ at both regional and national levels, as adopted in the third UN World Conference on Disaster Risk Reduction

$30 \quad$ World Bank, 'ASEAN Asia First Regional Climate Disaster Risk Financing Facility' (18 December 2018), available at <https://www.worldbank.org/en/news/feature/2018/12/18/ asean3-countries-establish-asias-first-regional-climate-and-disaster-risk-financingfacility>.

$31 \quad$ Ibid.

32 Ibid.

33 AHA Centre, 'Annual Report 2018: Breaking New Ground' (2018), available at <https://ahan centre.org/wp-content/uploads/2019/05/AHA-Centre-Annual-Report-2018-Digital.pdf>, 18-33.

$34 \quad$ Ibid., 18.

35 UN 'Sendai Framework for Disaster Risk Reduction 2015-2030' (18 March 2015) UN Doc A/ CONF.224/CRP.1. 
Conference in March 2015, which succeeded the Hyogo Framework for Action 2005-2015 (Hyogo Framework). ${ }^{36}$

More specifically, the ADRC aims not only to offer financial contributions but to facilitate multilateral cooperation in Asia and to strengthen D RR capacity of member countries with the help of advisor countries who shall provide their own expertise, experiences, and other resources through dispatching experts concerned with DRR to both member countries and the ADRC. ${ }^{37}$ On the other hand, member countries shall be encouraged to collect and disseminate information on DRR, and other related experiences and expertise and to share these resources among other member countries and the ADRC. ${ }^{38}$ The Centre was established in Kobe City of Hyogo Prefecture in Japan in July 1998, based on the agreement adopted in the Asian Disaster Reduction Cooperation Promotion Meeting held in June 1997. This agreement was inspired by the recommendations of the Yokohama Strategy and Plan of Action for a Safer World adopted in May 1994, ${ }^{39}$ which required each country to establish or strengthen regional or sub-regional centres for enhancing national capabilities on disaster reduction and prevention. ${ }^{40}$ The ADRC is organised into 31 Asian member countries, with Turkey recently joining the Centre in October $2018,{ }^{41}$ and five advisor countries outside the continent, ${ }^{42}$ as well as the chairman, who represents the ADRC and administrates its operation, and executive director who assists the chairman. ${ }^{43}$

In order to promote the Hyogo Framework in Asia, the AMCDRR has been co-organised by the host Asian country and the UN Office for Disaster Risk Reduction (UNISDR) every two years since 2005. Since 2015, it has subsequently

36 UN 'Hyogo Framework for Action 2005-2015: Building the Resilience of Nations and Communities to Disasters' (18-22 January 2005) UN Doc A/CONF.206/6 and Corr.1.

37 ADRC, 'The report of 20 years history of ADRC', articles of the Asian Disaster Reduction Center, available at <https://www.adrc.asia/publications/annual/2oth/2oth_Full.pdf>, preamble, art. 1, and art. 6, Annex 1.

38 Ibid., art. 5 .

39 UN, 'Yokohama Strategy for a Safer World: Guidelines for Natural Disaster Prevention, Preparedness and Mitigation and the Plan of Action of the World Conference on Natural Disaster Reduction, Yokohama, Japan' (23-27 May 1994) UN Doc A/CONF.172/9.

$40 \quad$ Ibid., para. $12(\mathrm{~A})$.

41 ADRC (n. 37) 5.

42 Member countries are Armenia, Azerbaijan, Bangladesh, Bhutan, Cambodia, China, India, Indonesia, Islamic Republic of Iran, Japan, Kazakhstan, Kyrgyz, Lao PDR, Malaysia, Maldives, Mongolia, Myanmar, Nepal, Pakistan, Papua New Guinea, Philippines, Republic of Korea, Russian Federation, Singapore, Sri Lanka, Tajikistan, Thailand, Turkey, Uzbekistan, Viet Nam, and Yemen. Advisor countries are Australia, France, New Zealand, Switzerland, and United States of America (US).

$43 \quad \operatorname{ADRC}($ n. 37) art. 9. 
emphasised the implementation of the Sendai Framework. The adoption of the first Asia regional plan was decided in the 7th AMCDRR held in New Delhi, India in November 2016, in line with the guiding principles and targets as provided in the Sendai Framework. The Plan included a long-term road map with a set of defined chronological milestones, and a two-year Action Plan with specific activities to be implemented during $2017-2018 .^{44}$ Based on the findings and progression realised, the next Action Plan for 2018-2020 defines a set of policy goals for the implementation of the Sendai Framework, including a long-term road map that clearly defines chronological milestones and special activities to be implemented.

\subsection{Progress in 2018}

From 3 to 6 July 2018, the 8th AMCDRR was held in Ulaanbaatar, Mongolia, to examine the implementation of the Sendai Framework, which underlines the need to carry out regional level actions through agreed regional and subregional strategies. In this conference, member States adopted the Action Plan 2018-2020 of the Asia Regional Plan to implement the Sendai Framework, ${ }^{45}$ as well as the Ulaanbaatar Declaration. ${ }^{46}$ This declaration is not legally binding but aims at generating political commitment for the implementation of the Sendai Framework in Asia. Among other things, it calls on all governments and stakeholders to ensure a human rights-based, people-centred and whole-ofsociety approach in the development, implementation and monitoring of national and local DRR strategies inclusive of women, children, persons with disabilities, older persons, displaced and migrant populations, among others. ${ }^{47}$ This provision seems to be inspired by the provisions of the Sendai Framework, especially noticeable at paragraph 7 in relation to a people-centred perspective, ${ }^{48}$ paragraph 19 (c) on a human-rights approach, ${ }^{49}$ and paragraph 19 (d) on an all-of-society perspective..$^{50}$ The development of appropriate legal frameworks and allocation of necessary resources was also required in this Declaration for the promotion of full and equal participation of women in

44 AMCDRR, 'Action Plan 2018-2020 of the Asia Regional Plan for Implementation of the Sendai Framework for Disaster Risk Reduction 2015-2030' (6 July 2018), available at $<$ https://www.preventionweb.net/english/professional/policies/v.php?id=59171>, 4. Ibid.

46 AMCDRR, 'Ulaanbaatar Declaration' (6 July 2018), available at <https://www.preventiont web.net/files/56219_ulaanbaatardeclarationfinal.pdf>.

47 Ibid., para. 11.

48 Sendai Framework (n. 35) para. 7.

49 Ibid., para. 19(c).

5o Ibid., para. $19(\mathrm{~d})$. 
leading, designing, and implementing DRR policies, plans and programmes, ${ }^{51}$ which is aligned with paragraph $17,27(\mathrm{a})$, and $48(\mathrm{~h})$ on the enhancement of legal frameworks in the Sendai Framework. ${ }^{52}$

On 9 May 2018, after the seventh Trilateral Summit, Japan, ROK, and China issued a joint declaration, acknowledging the importance of effective implementation of the Sendai Framework as well as reaffirming their commitment to strengthen trilateral cooperation in DRR and to continue to make joint efforts in raising public awareness, based on the framework as adopted in 2015. ${ }^{53}$

Furthermore, the three countries also cooperate with ASEAN through making use of the East Asia Summit (EAS), a regional forum for a dialogue among the head of the governments concerning various issues of regional and international community, which started in Kuala Lumpur, Malaysia, in December 2005. The EAS involves the ASEAN countries and eight external countries (Australia, China, Japan, India, New Zealand, Rok, Russian Federation, and the US). In the first session, they decided to include natural disaster mitigation as one of their priority fields. ${ }^{54}$ In November 2018, the EAS adopted the Chairman's Statement of its 13th Summit, encouraging further cooperation in disaster management and joint emergency response among the EAS participating countries in the occurrence of natural disasters. ${ }^{.5}$

\section{Collaboration with the IF RC}

In May 2018, the Disaster Law Programme of the IFRC and the ACDM officially launched the ASEAN Disaster Law Mapping project as a part of the a partnership to support the domestic implementation of disaster preparedness and response as provided in the AADMER, which had been in preparation since April 2017. ${ }^{56}$ In this project, the IFRC Disaster Law Programme aims to provide

$51 \quad$ Ulaanbaatar Declaration (n. 42) para. 12.

$5^{2}$ Sendai Framework (n. 35) paras. 17, 27 (a), 48 (h).

53 Ministry of Foreign Affairs of Japan, "The Joint Declaration of the Seventh Japan-ChinaROK Trilateral Summit' (9 May 2018), available at <https://www.mofa.go.jp/a_o/rp/paz ge4e_0oo817.html>.

54 Ministry of Foreign Affairs of Japan, 'Kuala Lumpur Declaration on the East Asia Summit, Kuala Lumpur' (14 December 2005), available at <https://www.mofa.go.jp/region/asiapaci/eas/jointo512.html>.

55 ASEan, 'Chairman's Statement of the 13th East Asia Summit, Singapore' (15 November 2018), available at <https://asean.org/storage/2018/11/East_Asia_Summit_Chairman_ Statement_Final.pdf $>$, para 18 .

56 IFRC, '2018 Southeast Asia Disaster Risk Governance Academic Seminar (24-26 September, Bangkok, Thailand)' (2018), available at <http://www.rcrc-resilience-southeastasia. org/wp-content/uploads/2019/o1/Report-Web-min.pdf>, 10. 
technical and research support to the ACDM under the AADMER Work Programme for 2016-2020. ${ }^{57}$

The IFRC also published a synthesis report for this project as a background study in $2017 .^{58}$ This report is part of a larger project to develop an online platform and other forms of peer learning on the implementation of the disaster preparedness and response elements of the AADMER at national level, showing the overall picture of regional trends in legal frameworks and policies on disaster risk management in the ten ASEAN member States. ${ }^{59}$ The analysis focuses on the extent to which the national laws and policies establish national disaster risk management systems that meet the domestic preparedness and response objectives of the AADMER, as well as how they designate roles and provide sufficient institutional responsibilities and powers for national institutions to undertake the regional coordination obligations for preparedness and response undertaken through the AADM ER. ${ }^{60} \mathrm{~A}$ key finding is that the AADMER provisions are not especially incorporated in national laws and regulations on disaster risk management, but that domestic frameworks are generally sufficient to meet the AADMER requirements relating to disaster preparedness and response. ${ }^{61}$

57 IFrC, 'Disaster Law Mapping ASEAn Agreement on Disaster Management and Emergency Response: The Context and Scope of this Project', available at <http://www.rcrcresilience-southeastasia.org/disaster-law/disaster-law-mapping-asean-agreement-ondisaster-management-and-emergency-response/about-this-project/>.

58 IFrC, 'ASEAn Disaster Law Mapping - Implementing AAdmer: A Regional Stocktake' (2017), available at <http://www.rcrc-resilience-southeastasia.org/wp-content/uploads/ 2018/o1/AADMER-Implementation-Regional-Report-FINAL-pdf.pdf>.

59 Ibid., 7 .

6o Ibid.

61 Ibid., 7-8. 